\title{
The Compendiosa of Thomas Geminus. Part I
}

\begin{abstract}
The first edition of Thomas Geminus's Compendiosa,' published in London in 1545, is both rare and a very important book. It is distinguished by being the first book printed in England with a title page printed from an engraved copper plate and is the first printed book in the world with copperplate anatomical illustrations. It marks the beginning of a move away from the practically exclusive use of woodcuts as the means of illustrating books and their gradual replacement by copperplate engravings, a process which was largely completed over the next century. It is perhaps a little ironic that this change followed very rapidly on the heels of the achievement of the peak of quality of the cutting of wood blocks for book illustration, a peak represented by the wood blocks cut in Venice for the first edition of Vesalius's Fabrica. But in retrospect it seems fitting that it was the images from those very woodcuts, copied and engraved on copper, that
\end{abstract} launched a new era in anatomical illustration and adumbrated the general switch from woodcut to copperplate engraving in book illustration. The Compendiosa was first described in detail by Larkey in 1933; though overtaken in a number of respects by later scholarship, his article is still well worth reading.

In 1543 Andreas Vesalius published the first edition of his new work on human anatomy, De Humani Corporis Fabrica Libri Septem (now universally known as his Fabrica), which was illustrated with a quite remarkable series of woodcuts representing human anatomy with a precision and elegance previously unknown. Before two years had elapsed Thomas Geminus copied these images for his Compendiosa engraving them on copper plates and, in many cases, arranging a number of images that were on different pages of the Fabrica on a single plate. Geminus's text - which may perhaps have been added as an afterthought to what was originally intended as a book of images only - is taken not from the Fabrica but from Vesalius's summary of this work, the Epitome, which was published along with the Fabrica in 1543; not surprisingly, this text does not correspond well with the images.

Geminus's engraved illustrations are the first to be used in an anatomy book making the techniques used in the creation of his plates of particular interest. While there had been scattered and sporadic use of engraved plates in printed books in the fifteenth century, the method was abandoned in favour of woodcuts whose quality improved over the century. The Compendiosa on the other hand was printed at the beginning of the revival in the sixteenth century of the use of engraved plates to illustrate printed works, a revival that would lead to a steady decline in the use of woodcuts until they virtually disappeared except from the very cheapest books.

The year after the publication of the Compendiosa Vesalius complained bitterly ${ }^{3}$ that his images had been copied incompetently, reduced in size and traduced in a recent English book. The inaccuracy of his comments suggests strongly that he had not himself seen the offending book and was basing his strictures on the reports of others. Nevertheless, the stricture of inaccuracy has rumbled on without anyone taking the trouble to compare Geminus's plates with the Vesalian originals in a way that would establish how accurate the copies are. I have now made such a comparison and hope to publish the results soon.

Although the imprint of the 1545 edition is that of John Herford, this refers only to the printing of the text. As Geminus tells us in the title, ('aere exarata per Thomam Geminum'), and confirms in his preface, he himself engraved the plates. What is more, if we accept his own statements in the preface of the 1545 edition at their face value, it appears that Geminus himself also printed his plates in compendium [...] communem studiorum usum in aere a me exaratum, impressi' (sig. 'leaf' recto). The preface to the 1553 English edition contains an extended and more emphatic English version of this - "beeynge all drawen out and graven in brasse and so impriented by myne owne labour' (sig. $\pi$ recto) - and also confirms that he drew and engraved the plates of the 1545 edition 'the first setting forth of thys work in Latin with the figures of my drawying and gravyng'. Of course we may wonder whether he really means that he himself carried out - or perhaps supervised - the printing of the plates or whether 'impressi' and 'imprinted' just mean 'caused to be printed'. This claim to have printed them himself, made at the very beginning of the revival of the use of engraved plates for book illustration, is of some importance since printing from copper plates required quite different equipment and a different technique than letterpress printing. 

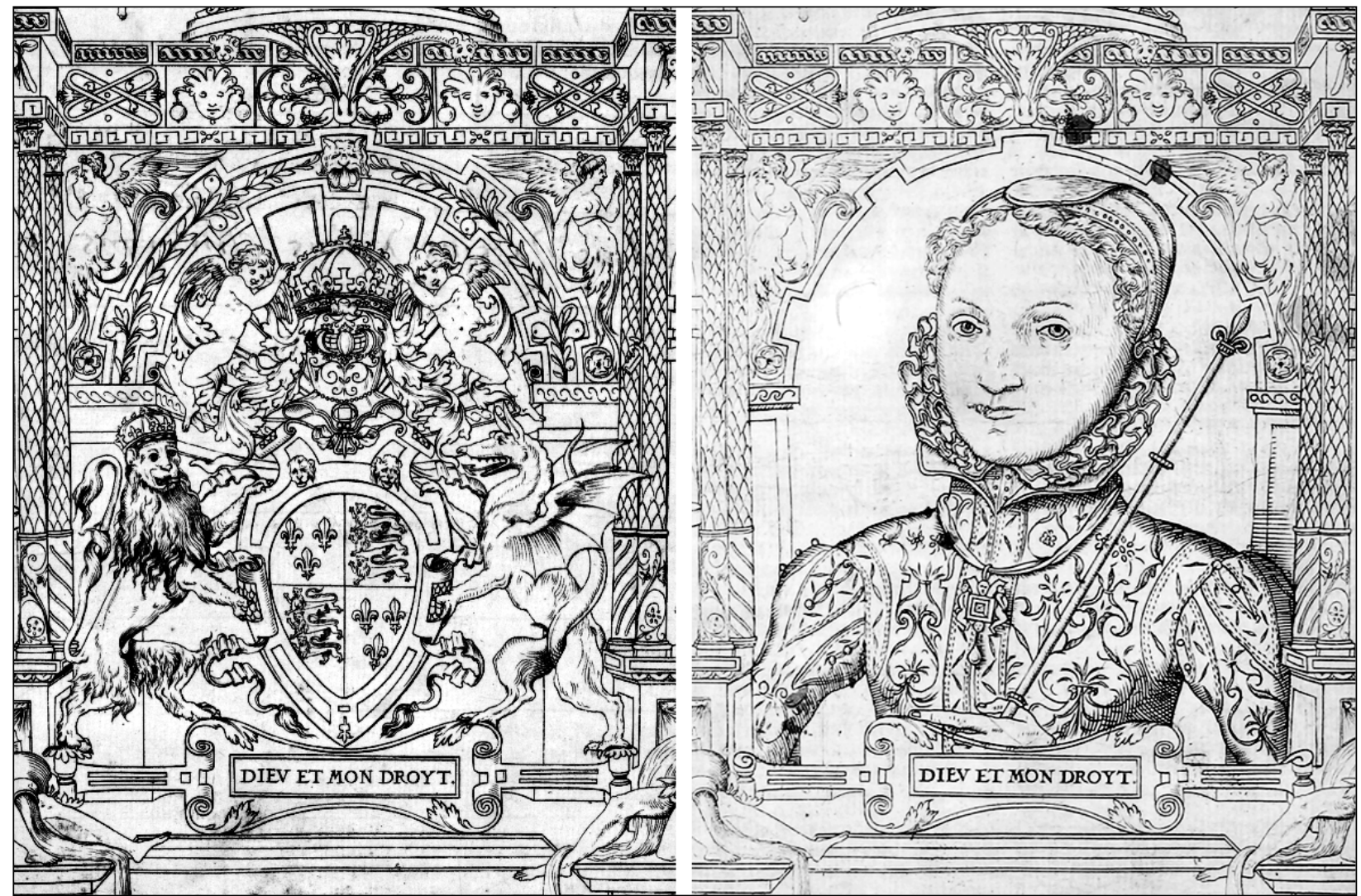

FIGURE | The centres of the title pages of the first 1545 (left) and third 1559 (right) editions of the Compendiosa. On the left, the first edition carries the arms of Henry VIII within an ornamented frame. In the third edition (right) the engraving of the centre of the plate has been beaten out and replaced by a a portrait of the young queen Elizabeth. Note that the frame has not been re-engraved and that the impression of the frame is fainter because of plate wear than it was in 1545 whereas the newly engraved portrait prints strongly. Both images are from copies of the books in the Sibbald Library.

\section{GEMINUS}

For many years very little was known of the identity of Thomas Geminus who was generally thought to have been an Italian. ${ }^{4}$ The best source for details of Geminus's life is an article by O'Malley in $1959^{5}$ from which it is now clear that he was a Fleming, born Thomas Lambrit, perhaps around 1520, near Liège in Flanders. He may have been a twin - as his nom de plume 'Geminus' suggests - certainly he had a brother Jasper to whom he left a bequest in his will. He was in England before 1544 and may have been a religious refugee. Geminus was primarily an engraver - of objects as well as illustrations, he engraved an astrolabe for Queen Elizabeth. He produced three editions of the Compendiosa; with Latin text in 1545 and English text from a quite different source (not a translation of the Vesalian Latin of the first edition) in 1553 and 1559 . In 1555 he engraved two maps and set up as a printer - that is, he printed letterpress as well as images - near Blackfriars from where he illustrated two editions of Leonard Digges's Prognostication of Right Good Effect. In receipt of an annuity from Henry VIII in 1546, he practised as a surgeon later receiving wages from Edward $\mathrm{VI}$ but his illegal medical practice was stopped in $1555 / 6$ by the Royal College of Physicians of London for whom he then printed a document in lieu of a fine. The third edition of the Compendiosa in 1559 carries the colophon 'Imprinted at London within the blacke fryars: by Thomas Gemini' indicating that the text (letterpress) as well as the plates were printed by Geminus.

Of course, we do not know to what extent (if any) Geminus himself carried out all the tasks involved in printing from type but he must certainly have headed the enterprise. By his own account he drew as well as engraved his plates, copying from Vesalius's images, again as he himself says, and apparently printing the images from the plates himself. A little later this would have been a most unusual combination of skills. It was usual for copperplate engravers to work from drawings supplied to them and the engravers did not usually make the prints from the plates; this was done by specialised plate printers using presses quite different from those used for letterpress. If we take Geminus at his word and there is no reason to do otherwise - at the very beginning of the revival of copperplate engraving for book illustration we have a single craftsman who was master of the whole process of copperplate illustration from drawing to printed sheet as well as printing (or perhaps managing the printing) of letterpress from type. 


\section{RE-WORKING OF PLATES AS EVIDENCE OF GEMINUS'S SKILL AS AN ENGRAVER}

Two plates of the 1545 edition exist in an early and a late state; our copy has the early state. The details of these two states and their significance in showing how Thomas Geminus was able to alter two of the copper plates of anatomical images during the life of the edition are discussed in detail by Donaldson (2010).

Two subsequent editions of the Compendiosa (I552/3 and 1559) and the two anatomical works published by André Wechel in Paris in 1564 and 1569, which use images from the same plates, present them in the later state. The Sibbald Library of the Royal College of Physicians of Edinburgh is fortunate to hold a copy of the 1545 Compendiosa in its early state, as well as the 1559 edition and both of the Parisian editions.

In addition, the title page of the 1559 (third) edition differs in two respects from that of the first two editions. Most strikingly, the centre of the plate which in the earlier editions carries the royal arms of Henry VIII is replaced by a portrait of the young Queen Elizabeth who had acceded to the throne the previous year (1558). But this new title page was not printed from a new plate. Rather, the change was achieved by erasing the centre of the plate and engraving the portrait over the now blank metal. The erasure was not completely perfect and traces of a couple of the lines of the earlier engraving are visible on minute examination.The lettering of the cartouche of the 1559 edition is also subtly different from that of the first two editions. Larkey ${ }^{2}$ remarked that 'the type is slightly different' but this comment is misleading since it suggests that the lettering was printed from movable type whereas it is in fact engraved on the plate along with the image. The details of the changes (which are a little complex) are explained in my paper of 2010.6 In summary, flourishes were added to two letters and others were strengthened. I also set out there the evidence that makes it quite certain that the I 559 plate is a partial re-working of the earlier plate and not a completely new engraving.

From the quality of the engraving of the plates, which is more than competent, and the evidence of the subtle re-working of some of the plates, it is apparent that, though Geminus was working at the very beginning of the revival of copperplate engraving for book illustration, he was a master of engraving techniques. Where he learned his craft we do not know but it may be significant that he was a Fleming and that engraving of images - though not yet their use in book illustration was carried out at this time in the Netherlands.

Geminus died between 22 May (the date of his will) and 27 May 1562 when probate was granted.

\section{RE-USE OF THE IMAGES FROM THE COMPENDIOSA}

After Geminus's death the anatomical engravings of the Compendiosa were used to illustrate two editions of Vesalius's Epitome, one Latin in $1564^{7}$ and one French in $1569,{ }^{8}$ published by the Parisian printer and publisher André Wechel in association with the French poet and anatomist Jacques Grévin. How Wechel acquired Geminus's illustrations has been a matter of considerable speculation; the question has now been partially resolved by the recent discovery and partial decipherment of a document in a Parisian archive. This fascinating story is too involved and too long to tell here; suffice it to say that I believe there is fairly compelling evidence that the illustrations in the Parisian editions had been printed in London - possibly during Geminus's life - and that Wechel is unlikely to have made use of Geminus's copper plates though they were probably in his possession. Finally, Grévin's text and commentary for the Parisian editions was reused by Plantin in Antwerp in 1566 for an edition, Vivae Imagines Partium Corporis Humani Aereis Formis Expressae, illustrated with new plates derived from a set originally engraved for Valverde in 1556 and heavily influenced by Geminus. The influence of Geminus's engravings continues to be seen in the illustrations of anatomical works for at least the next century.

In the second part of this article we shall consider, among other matters, details of the Library's copy of the first edition of the Compendiosa and some examples of Geminus's plates.

IML Donaldson, Honorary Librarian, RCPE (email: i.m.l.d@ed.ac.uk)

\section{References}

I Geminus T. Compendiosa totius anatomie, ære exarata: per Thomam Geminum. London: 1545.

2 Larkey SV. The Vesalian Compendium of Geminus and Nicholas Udall's translation. Transactions of the Bibliographical Society (2nd series) 1933; 13:367-94.

3 Vesalius A. Andreae Vesalii Bruxellensis, Medici Caesarei epistola, rationem modumque propinandi radicis Chynae. Basel: Johann Oporinus; I546. The so-called 'China Root Letter'. See pp. 4-5 and p. 199 for criticisms of the illustrations in the Compendiosa.

4 Keynes G.The anatomy of Thomas Geminus. A notable acquisition for the Library. Annals of the Royal College of Surgeons of England 1959; 25: I7I-5.

5 O'Malley CD. Thomas Geminus Compendiosa totius anatomie delineatio. A facsimile of the first English Edition of 1553 in the version of Nicholas Udall. With an introduction by C.D. O'Malley. London: Dawson's of Pall Mall; 1959.

6 Donaldson IML. Two states of some plates in the Compendiosa of Thomas Geminus (1545). The Library (7th series) 2010; I I:89-104.

7 Vesalius A, Grévin J. Anatomes totius, aere insculpta delineatio, cui addita est epitome... quam De corporis humani fabrica conscripsit clariiss [sic] .... Paris: André Wechel; I564. (reissued in 1565 with the error in the title corrected).

8 Vesalius A, Grévin J. Les portraicts anatomiques de toutes les parties du corps humain.../par Jaques Grévin. Paris:André Wechel; I569. 


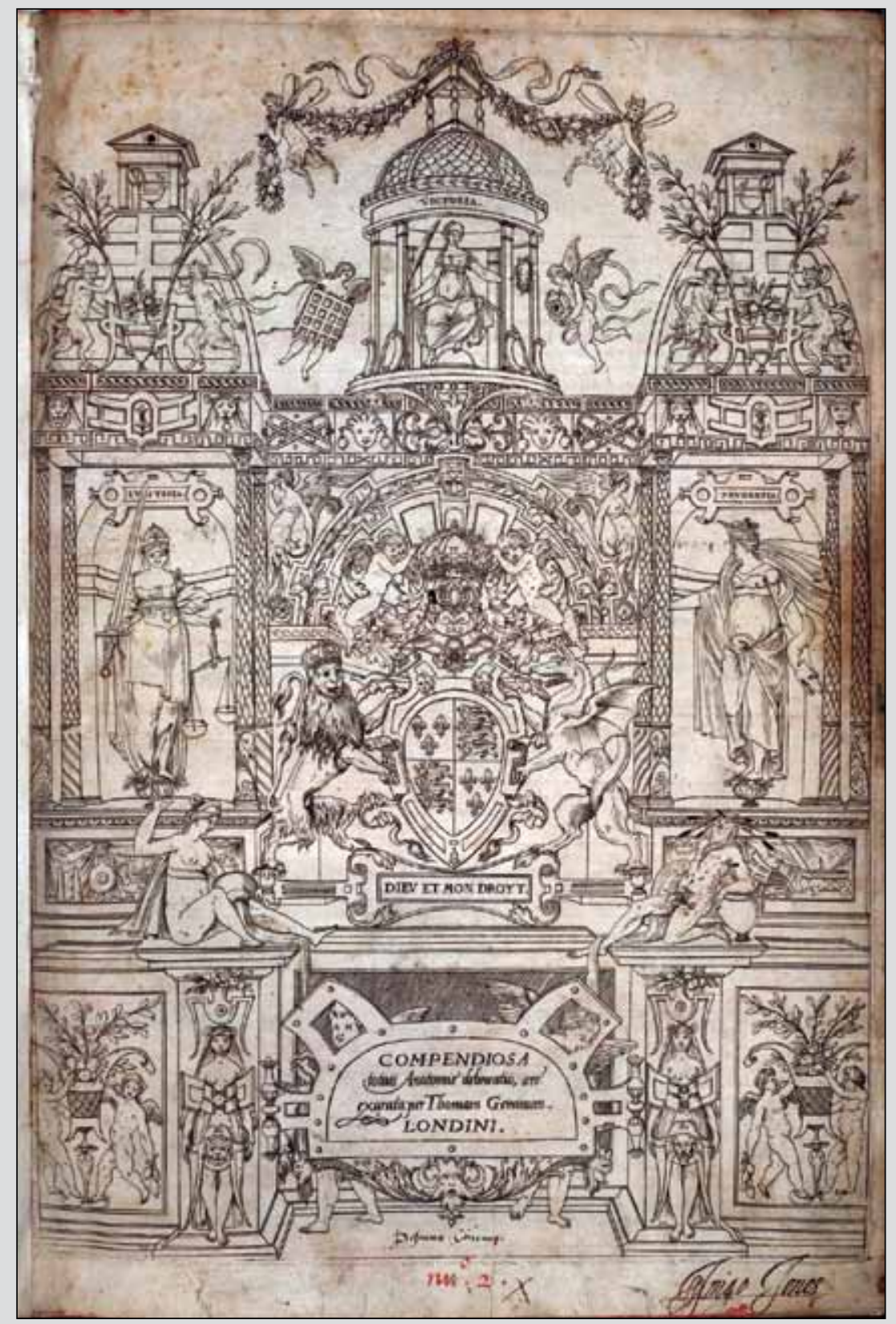

Title page of the first edition of Compendiosa totius anatomie delineatio, ære exarata: perThomam Geminum, London 1545. This book of illustrations of human anatomy, copied from the woodcuts of the Fabrica of Andreas Vesalius of 1543 and engraved on copper plates by Thomas Geminus, has the first title page printed from a copper plate in England. Dedicated to King Henry VIII, it carries his arms framed by an exuberant set of images including three female figures representing Victory (top), Justice (left) and Prudence (right). This copy, in the Sibbald Library of the RCPE, was owned in 1546 by the French surgeon François Rasse Desneux whose short ex libris, Desneux Chirurg., is seen in manuscript under the centre of the cartouche containing the title and whose name in full is on the obverse of the title page. It was later in the possession of Inigo Jones whose signature is on the bottom right corner of the page. For more details of the book see the article on pages $85-87$ of this issue. 